\title{
Handheld Laser Scanning Detects Spatiotemporal Differences in the Development of Structural Traits among Species in Restoration Plantings
}

\author{
Nicolò Camarretta ${ }^{1,2, * \mathbb{D}}$, Peter A. Harrison ${ }^{2} \mathbb{D}$, Arko Lucieer $^{3}{ }^{(D}$, Brad M. Potts ${ }^{2} \mathbb{D}$, Neil Davidson ${ }^{4}$ \\ and Mark Hunt ${ }^{2}$ \\ 1 Bioclimatology, Faculty of Forest Sciences and Forest Ecology, University of Goettingen, \\ 37077 Göttingen, Germany \\ 2 School of Natural Sciences \& ARC Training Centre for Forest Value, University of Tasmania, \\ Hobart 7001, Australia; P.A.Harrison@utas.edu.au (P.A.H.); b.m.potts@utas.edu.au (B.M.P.); \\ m.hunt@utas.edu.au (M.H.) \\ 3 School of Geography, Planning and Spatial Sciences, University of Tasmania, Hobart 7001, Australia; \\ Arko.Lucieer@utas.edu.au \\ 4 Greening Australia, Mount Nelson 7007, Australia; neil53davidson@gmail.com \\ * Correspondence: Nicolo.Camarretta@uni-goettingen.de
}

check for updates

Citation: Camarretta, N.; Harrison, P.A.; Lucieer, A.; Potts, B.M.; Davidson, N.; Hunt, M. Handheld Laser Scanning Detects Spatiotemporal Differences in the Development of Structural Traits among Species in Restoration Plantings. Remote Sens. 2021, 13, 1706 https://doi.org/10.3390/rs13091706

Academic Editor: Glen S. Brown

Received: 16 March 2021

Accepted: 24 April 2021

Published: 28 April 2021

Publisher's Note: MDPI stays neutral with regard to jurisdictional claims in published maps and institutional affiliations.

Copyright: (c) 2021 by the authors. Licensee MDPI, Basel, Switzerland. This article is an open access article distributed under the terms and conditions of the Creative Commons Attribution (CC BY) license (https:// creativecommons.org/licenses/by/ $4.0 /)$.

\begin{abstract}
A major challenge in ecological restoration is assessing the success of restoration plantings in producing habitats that provide the desired ecosystem functions and services. Forest structural complexity and biomass accumulation are key measures used to monitor restoration success and are important factors determining animal habitat availability and carbon sequestration. Monitoring their development through time using traditional field measurements can be costly and impractical, particularly at the landscape-scale, which is a common requirement in ecological restoration. We explored the application of proximal sensing technology as an alternative to traditional field surveys to capture the development of key forest structural traits in a restoration planting in the Midlands of Tasmania, Australia. We report the use of a hand-held laser scanner (ZEB1) to measure annual changes in structural traits at the tree-level, in a mixed species common-garden experiment from seven- to nine-years after planting. Using very dense point clouds, we derived estimates of multiple structural traits, including above ground biomass, tree height, stem diameter, crown dimensions, and crown properties. We detected annual increases in most LiDAR-derived traits, with individual crowns becoming increasingly interconnected. Time by species interaction were detected, and were associated with differences in productivity between species. We show the potential for remote sensing technology to monitor temporal changes in forest structural traits, as well as to provide base-line measures from which to assess the restoration trajectory towards a desired state.
\end{abstract}

Keywords: hand-held laser scanning; ZEB1; LiDAR; structural attributes; species variation; individual tree; tree architecture; Eucalyptus

\section{Introduction}

To counter the effects of climate change, multiple nations have pledged to restore hundreds of millions of hectares of degraded land by re-establishing biodiverse plantings for biomass and carbon sequestration, and conserving biodiversity. The monitoring of these plantings will be pivotal in reporting their effectiveness in reaching the desired restoration targets [1]. Recently, it has been argued that key response traits, also referred to as Essential Biodiversity Variables (EBVs), need to be identified in order for ecosystem monitoring to be effective [2]. One such EBV that could serve as a viable candidate to monitor the effectiveness of forest restoration plantings is forest structural complexity [3], which is considered a reliable indicator of ecosystem health and function [4]. Greater forest structural complexity is expected to provide a greater diversity of habitats for species. Tree species 
composition can have impacts on pollinators [5], and biomass accumulation [6], while the presence of different forest tree species may result in the formation of several canopy layers, which positively affect bird communities [7] and mammal populations [8]. Unfortunately, the use of traditional field inventories for the assessment of spatial and temporal changes in forest structural complexity and forest structural traits can be expensive and time demanding [4]. Consequently, interest is growing in the restoration community towards using remote sensing applications to provide a timely and cost-effective alternative [9-11].

While remote sensing applications increasingly have been adopted for the assessment of forest structural traits in production forestry [12], the uptake of these technologies in a restoration context is proving slow and challenging [9], and has remained largely focused on the initial planning phase [10]. Light Detection and Ranging (LiDAR) data can capture detailed characteristics of forest structural traits [13], as the key data obtained are the threedimensional (3D) point cloud that reflects the location in space of the objects hit by the laser beams [14]. These point clouds can vary in terms of density (e.g., from $<1$ point $/ \mathrm{m}^{2}$ to $>100$ points $/ \mathrm{m}^{2}$ ), according to the sensor specifications, the Earth observation platform carrying them, and the scale and scope of investigation. When the study aims to obtain very detailed information of below-canopy elements over small areas, ground-based LiDAR systems (also referred to as proximal sensing) can be used [15,16]. Proximal sensing offers a clear advantage compared to airborne remote sensing-being on the ground and embedded in the vegetation system, proximal sensing provides an advantageous perspective on ground vegetation and below-canopy elements. Ground-based LiDAR can be either static (i.e., mounted on a tripod-terrestrial laser scanner (TLS)) or mobile (i.e., mounted on a vehicle or hand-held-hand-held mobile laser scanner (HMLS)). Regarding the acquired information, TLS systems provide the most accurate datasets, with extremely dense 3D point clouds and the addition of RGB imagery collected during each scan. Nevertheless, since TLS produces $360^{\circ}$ scans from a fixed position, a single scan will only acquire data from the side of the trees facing the instrument (thus losing the information on the other side, due to occlusion). To reduce the occlusion due to the limited line-of-sight in forests, TLS users need to carry out multiple scans to cover the study area, thus increasing data acquisition times and requiring extensive site preparation and pre-processing [17]. Alternatively, mobile systems can be used to capture detailed 3D information, simply by scanning the trees as one walks through the study area [18]. The main limitations of HMLS are: (i) the lack of a built-in global navigation satellite system (i.e., GNSS) unit (i.e., no information on the geolocation of the scan); (ii) a maximum scanning distance of 15-20 m (this can vary according to the instrument), which results in a height cut off when scanning tall trees; and (iii) reduced accuracies when compared to TLS [19]. Nonetheless, when monitoring the development of young trees, HMLS is advantageous as data collection using TLS would require an extremely large number of scanning positions to account for the often dense "bush-like" nature of young growing trees. In addition, HMLS are easy to use and can be operated with little to no previous experience in remote sensing or surveying. This feature makes the use of HMLS systems extremely appealing to restoration ecologist, since the only real need for specialized personnel to carry out regular monitoring is related to the very early plot establishment phase (namely the precise acquisition of the coordinates of ground control points-see Section 2.2).

Given the current dearth of studies monitoring the success of forest restoration plantings over time, particularly through the aid of remote sensing technologies, we here aim to test and validate for the first time the use of proximal LiDAR data acquired using a HMLS (i.e., ZEB1 system) to monitor the development of several structural traits. This is carried out at the individual tree-level in a eucalypt dominated, mixed species restoration planting over a three-year period. In particular, we focus on (i) how well key structural attributes measured in the field are estimated using LiDAR, (ii) how structural attributes change through time, and (iii) determine whether these structural attributes differ among species. 


\section{Materials and Methods}

\subsection{Study Site}

The study was carried out at the Dungrove restoration research site (592 m elevation, latitude $-42.2733^{\circ}$, longitude $\left.146.8941^{\circ}\right)$, located in the southern Midlands of Tasmania, Australia (Figure 1a). The Dungrove research experiment was established in 2010 on exagricultural land, embedded in broader restoration plantings aimed at the re-connection of remnant dry eucalypt woodlands, dominated by Eucalyptus pauciflora and E. tenuiramis [20]. As part of the experiment, eight replicates with twelve community treatments of 120 trees each, have been planted across the landscape. These treatments differed according to the species planted as immediate neighbor to the focal eucalypt (i.e., E. pauciflora and E. tenuiramis), and comprised of monocultures and mixed species plots [21].

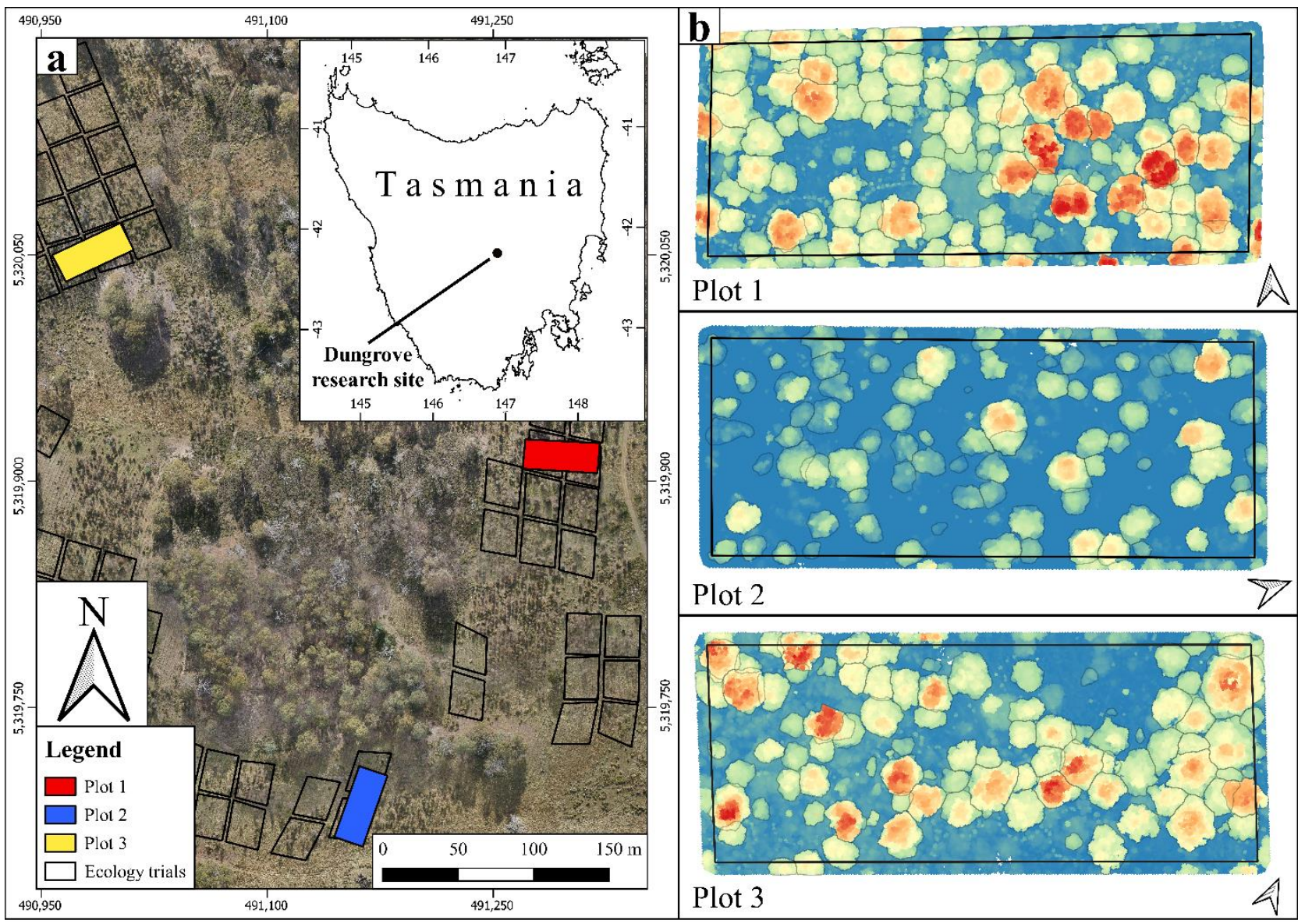

Figure 1. (a) The Dungrove research site showing the locations of the three permanent plots (red, blue, yellow polygons) superimposed over the broader experimental plantings of the Ecology trial (black polygons) and site position within Tasmania (inset map—coordinates in WGS 84, EPSG:4326); (b) the three Canopy Height Models (CHMs) of the ZEB1 plots, acquired in 2019, shown with individual crowns overlaid and their $50 \times 20 \mathrm{~m}$ bounding box, colored according to aboveground height (blue to red $=0-10 \mathrm{~m}$ ). The coordinate system used in map (a) is GDA94/MGA zone 55S, EPSG:28355.

\subsection{ZEB1 Data Acquisition and Co-Registration}

ZEB1 (GeoSLAM ${ }^{\mathrm{TM}}$, Nottingham, UK) data collection was carried out in three $50 \times 20 \mathrm{~m}$ quadrats ( 0.1 ha) over a three-year time period: first-year measurements were conducted at the end of February 2017, while second- and third-year scans were carried out in early May 2018 and early April 2019, respectively, which was seven to nine years after planting. The ZEB1 system is provided with a Hokuyo UTM-30LX laser scanner, operating at a wavelength of $905 \mathrm{~nm}$. It has a horizontal and vertical field of view of approximately $270^{\circ}$ and $120^{\circ}$, respectively, and a maximum scanning range of $30 \mathrm{~m}$ (typical maximum range 15-20 m). It can scan up to 40 lines/s and 43,200 points/s [22]. The lack of a built-in GNSS (or GPS) 
unit inside the ZEB1 system required the development of a standard sampling protocol to allow for the co-registration of each scan in real world coordinates. This sampling protocol needs a semi-fixed set-up for each sampling quadrat: eight permanent reference pickets (i.e., $0.9 \mathrm{~m}$ steel fencing posts) were driven halfway into the ground in each quadrat, one in each corner, while the remaining four were scattered throughout the plot. At the start of the study, the position of each reference picket was georeferenced using a GNSS receiver transmitting to a nearby base station.

Before each ZEB1 scan, a $1.8 \mathrm{~m}$ plastic coated steel pole was fixed to each reference picket. A $0.2 \mathrm{~m}$ diameter polystyrene reference target was placed on its top (Figure 2), then the height from the ground to the base of the reference target was recorded. Once the data was processed by the proprietary software and it was returned to the end user in a readable format (.las), this reference height, together with the ground coordinates of each reference point was used to co-register the point cloud to the GDA94-MGA zone 55 coordinate reference system (EPSG: 28355). Point cloud co-registration was carried out in the open-source software CloudCompare v2.9.1 (http: / / cloudcompare.org/, accessed on 17 September 2017) using the "align (point pairs picking)" function. The four corner references were used to register each point cloud, while the remaining reference points were used to assess the final root mean squared error (RMSE) for each scan (Table 1). Finally, each scan was clipped to its permanent bounding box of $50 \times 20 \mathrm{~m}$, with a $1 \mathrm{~m}$ external buffer to avoid cutting out parts of the bordering crowns. The external buffer was created in the opensource QGIS environment (QGIS Desktop version 2.18.0), while the clipping was carried out using the "lasclip" function from LasTools (https:/ / rapidlasso.com/lastools/lasclip/, accessed on 17 September 2017).

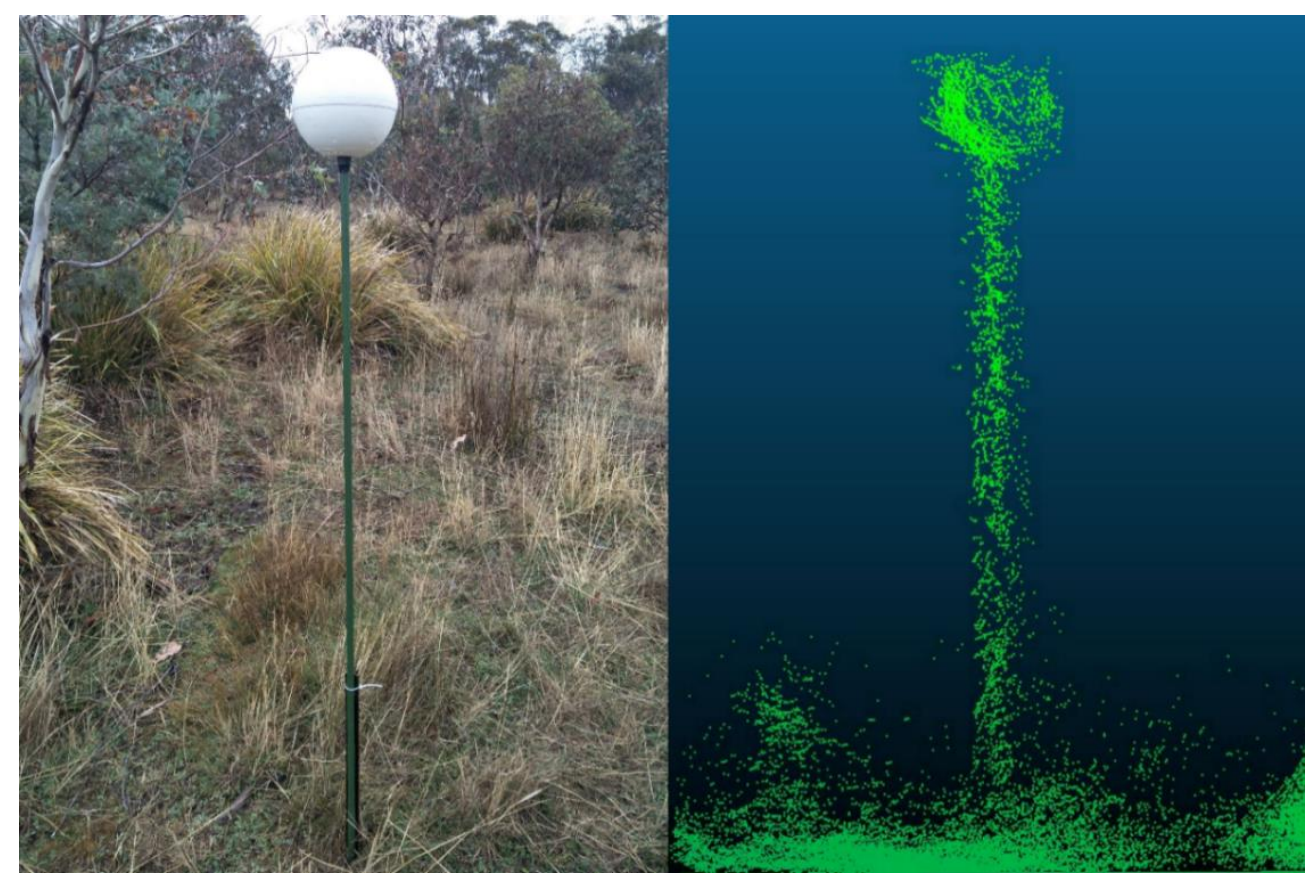

Figure 2. Reference target on top of its support used in the field (left) and its captured 3D point cloud (right). 
Table 1. Summary statistics of ZEB1 data registration for each of the three monitoring plots over the three monitoring years. Shown for each plot is the scanning date, the registration root mean squared error (RMSE), the mean number of points per square meter, and the mean, maximum, and standard deviation of the individual tree height.

\begin{tabular}{|c|c|c|c|c|c|c|}
\hline Plot & Acquisition Date & $\begin{array}{l}\text { Registration } \\
\text { RMSE (m) }\end{array}$ & Points $/ \mathrm{m}^{2}$ & $\begin{array}{c}\text { Mean } \\
\text { Height (m) }\end{array}$ & $\begin{array}{c}\text { Max } \\
\text { Height (m) }\end{array}$ & $\begin{array}{c}\text { Standard } \\
\text { Deviation }(\mathrm{m})\end{array}$ \\
\hline \multirow{3}{*}{1} & 21 February 2017 & $0.14^{\mathrm{a}}$ & $12,822.6$ & 2.27 & 7.38 & 0.77 \\
\hline & 15 May 2018 & $0.20^{\mathrm{a}}$ & $15,522.2$ & 2.34 & 8.35 & 0.84 \\
\hline & 2 April 2019 & $0.19^{a}$ & $14,543.2$ & 2.24 & 8.93 & 0.82 \\
\hline \multirow{3}{*}{2} & 20 February 2017 & 0.11 & 6149.3 & 1.96 & 5.40 & 0.52 \\
\hline & 15 May 2018 & 0.29 & $11,543.0$ & 2.18 & 6.48 & 0.66 \\
\hline & 10 May 2019 & 0.20 & $14,159.6$ & 2.07 & 6.42 & 0.65 \\
\hline \multirow{3}{*}{3} & 21 February 2017 & 0.15 & 7919.7 & 2.28 & 7.52 & 0.79 \\
\hline & 15 May $2018^{\text {b }}$ & $0.13^{\mathrm{a}}$ & $13,502.2$ & 2.33 & 7.94 & 0.85 \\
\hline & 2 April 2019 & 0.16 & 8085.1 & 2.19 & 8.22 & 0.74 \\
\hline
\end{tabular}

a RMSE computed using three control points instead of four. ${ }^{b}$ Point cloud registration using three of the four corner reference points plus the closest reference point, from those inside the plot, to the unrepresented corner.

\subsection{Individual Tree and Plot-Level Structural Trait Extraction}

Once registered, the point clouds were used to create nine (i.e., one per plot per year) Canopy Height Models (CHMs), using the "Lasgrid" function from LAStools (https: / / rapidlasso.com/lastools/lasgrid/, accessed on 17 September 2017). These nine CHMs were loaded into the open access QGIS environment (see above) and used (with the aid of the restoration planting layout) to manually digitize the crowns of approximately 270 trees (Figure 1b). Although the outline of most tree crowns was easily detectable, for a small subset of neighboring trees with overlapping crowns, further data manipulation proved necessary. In such cases, manual segmentation of overlapping crowns was achieved using the "segment" function from CloudCompare (Figure 3). Once individual tree crowns were segmented, the extraction and calculation of structural traits at the individual treelevel (Table 2) was carried out using the statistical language $R$ [23]. These structural traits were chosen as they have been previously shown to significantly vary between and within species [11] and are presented as potential proxies for characterizing the return of structural complexity in ecological restoration plantings. To estimate above-ground biomass (AGB) and diameter at breast height $(\mathrm{DBH})$ from the LiDAR point clouds, we applied the following allometric equations by Jucker et al [24]:

$$
\begin{gathered}
\mathrm{AGB}=(0.016) \times(\mathrm{H} \times \mathrm{CD})^{(2.013)} \times \exp \left[0.204^{2} / 2\right], \\
\mathrm{DBH}=0.557 \times(\mathrm{H} \times \mathrm{CD})^{0.809} \times \exp \left[0.056^{2} / 2\right]
\end{gathered}
$$

where $\mathrm{H}$ represents tree height (in meters), CD stands for crown diameter (in meters), and AGB is dried biomass (in $\mathrm{kg}$ ). These allometric equations were developed using $>100,000$ measurements from a diversity of tree species across many biomes, specifically for remote sensing [24]. In the case of tree height, we used the 99th percentile height estimated from each point cloud. This measure of tree height was chosen as preliminary analyses detected significant outlying points at the top of the point clouds, most likely due to the detection of objects other than the canopy, such as birds. 


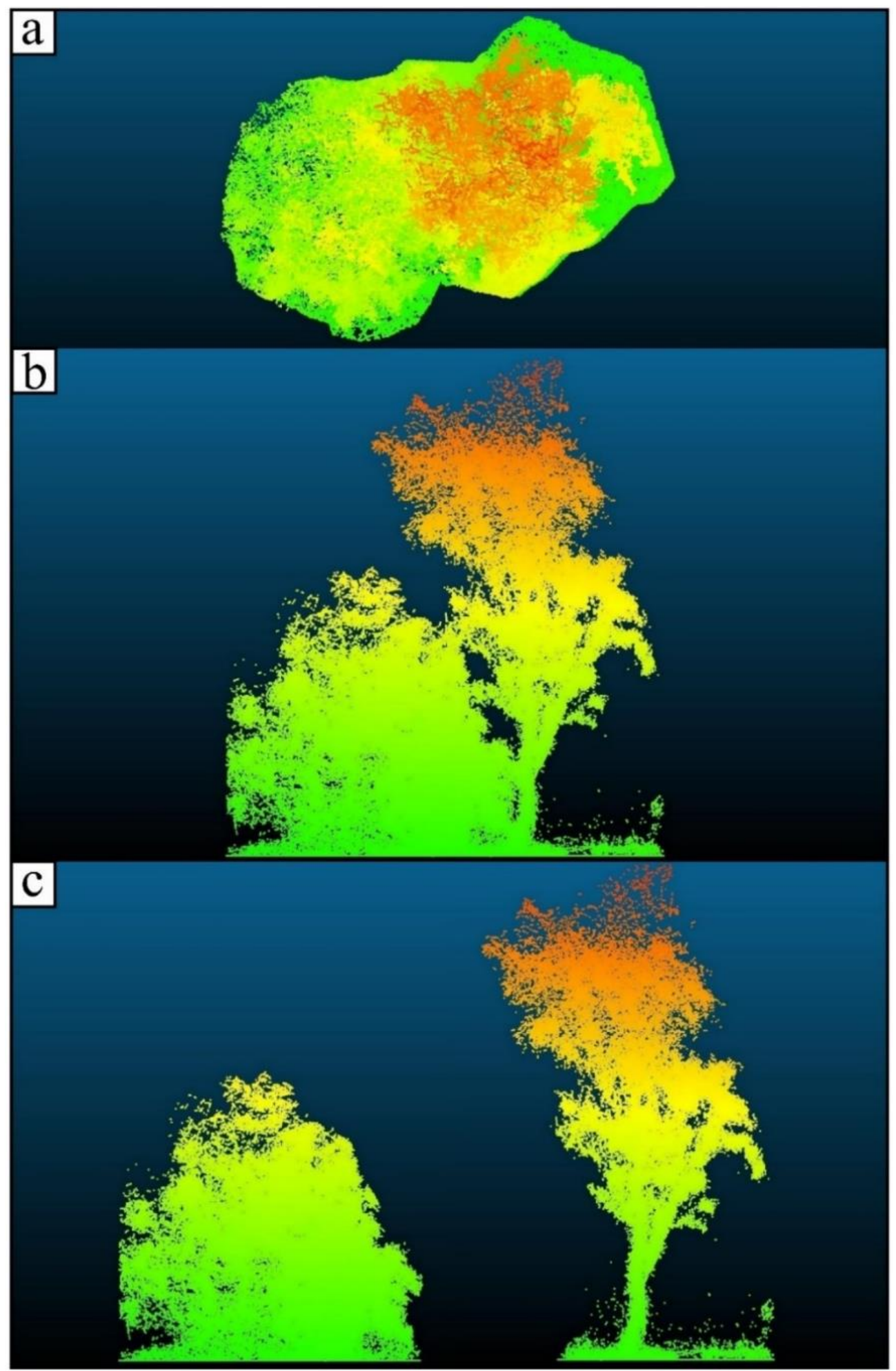

Figure 3. 2D representation of an example point cloud of two neighboring, overlapping crowns seen from above (a) and from the side (b), and the individual point clouds of both trees after manual separation (c). 
Table 2. List and description of the 15 structural traits computed for each individual tree extracted from the LiDAR point clouds.

\begin{tabular}{|c|c|}
\hline Structural Traits & Description of LiDAR-Derived Traits \\
\hline Height P99 (m) & 99th percentile of height within point cloud. \\
\hline Crown skewness & $\begin{array}{l}\text { Skewness of the height distribution within each tree } \\
\text { (median - Q1)/(Q3 - median). }\end{array}$ \\
\hline Height of widest cross-section (m) & Height of the crown at its widest cross-section. \\
\hline Max crown diameter $(\mathrm{m})$ & $\begin{array}{l}\text { The widest cross-section of the crown in any } \\
\text { given direction. }\end{array}$ \\
\hline Crown volume (convex hull-m³) & $\begin{array}{l}\text { Crown volume of a 3D convex hull calculated from } \\
\text { the point cloud defined above crown insertion. It is } \\
\text { calculated using the "convhulln" function of the R } \\
\text { geometry package. }\end{array}$ \\
\hline Crown surface area $\left(\mathrm{m}^{2}\right)$ & $\begin{array}{c}\text { The surface area of a 3D convex hull calculated } \\
\text { using the point cloud defined above the canopy } \\
\text { insertion point. }\end{array}$ \\
\hline Crown projected area $\left(\mathrm{m}^{2}\right)$ & $\begin{array}{l}\text { The area of the projected polygon describing the } \\
\text { crown ground cover. }\end{array}$ \\
\hline Height to area ratio $\left(\mathrm{m} / \mathrm{m}^{2}\right)$ & $\begin{array}{l}\text { The ratio of tree height to crown surface area. It } \\
\text { represents the total height of the tree per unit of area. }\end{array}$ \\
\hline Height to volume ratio $\left(\mathrm{m} / \mathrm{m}^{3}\right)$ & $\begin{array}{l}\text { The ratio of tree height to crown volume. It } \\
\text { represents the total height of the tree per unit } \\
\text { of volume. }\end{array}$ \\
\hline Points to area ratio (points $/ \mathrm{m}^{2}$ ) & $\begin{array}{l}\text { The ratio of number of points in the crown to crown } \\
\text { surface area, representing a proxy for crown density. }\end{array}$ \\
\hline Points to volume ratio (points $/ \mathrm{m}^{3}$ ) & $\begin{array}{l}\text { The ratio of number of points in the crown to crown } \\
\text { volume, representing a proxy for crown density. }\end{array}$ \\
\hline Above Ground Biomass (AGB-kg) & $\begin{array}{l}\text { AGB estimated through the allometric Equation (1) } \\
\text { developed by Jucker et al. [24], using Tree height } \\
\text { and Max crown width. Measured as dry weight. }\end{array}$ \\
\hline Diameter at breast height $(\mathrm{cm})$ & $\begin{array}{c}\text { Diameter at } 1.3 \mathrm{~m} \text {, derived from a general allometric } \\
\text { Equation (2) using total tree height and maximum } \\
\text { crown width [24]. }\end{array}$ \\
\hline Rumple index & $\begin{array}{l}\text { Calculated as the ratio between crown surface area } \\
\text { on ground surface area, this index reflects crown } \\
\text { structural complexity. Calculated using the } \\
\text { "rumple_index" function from the lidR package. }\end{array}$ \\
\hline Area (3D:2D) & $\begin{array}{l}\text { The ratio between crown volume calculated from the } \\
\text { point cloud (i.e., convex hull) and the crown area } \\
\text { obtained from the projected polygon. }\end{array}$ \\
\hline
\end{tabular}

To quantify the temporal gap dynamics at the plot-level, the number and total size of gaps were estimated for each plot across the three monitoring years using the ForestGapR $\mathrm{R}$ package [25]. Here, for each monitoring year, a pit-free $\mathrm{CHM}$ was calculated for each plot using the "grid_canopy function of lidR as input to the "getForestGap" function to detect gaps at $0.1 \mathrm{~m}$ cumulative threshold from ground to maximum height of the CHM. The total number of gaps and their combined area $\left(\mathrm{m}^{2}\right)$ were obtained for each cumulative threshold using the "GapStats" function.

\subsection{Ground-Based Measurements}

A subset of the LiDAR-derived structural traits was validated using equivalent groundbased measurements of all trees in the three plots. These included: diameter at breast height $(\mathrm{DBH})$ of all stems $>1 \mathrm{~cm}$, tree height, crown insertion height, and crown dimensions 
(two diagonal measurements of the crown). Here, crown insertion height is defined as the vertical distance from the ground to the lowest branch of the main tree crown. These measures were carried out at approximately the same time as the ZEB1 data acquisition. The measurements of crown dimensions and crown insertion height were taken only during the second and third year of the study.

\subsection{Statistical Analysis}

All statistical analysis and data visualization were undertaken in R [23]. Trait validation was carried out by fitting a linear regression model associating the field measured traits for each tree with the point cloud derived estimates of the same trait, and $\mathrm{R}^{2}$ values for each trait calculated. The model assumption of normality and homoscedasticity as well as overdispersion were statistically and visually assessed using simulated residuals from the fitted model using the "simulateResiduals" function of the DHARMa package). The only trait that required transformation was $\mathrm{DBH}$, which was transformed using the natural logarithm and back transformed for visualizing the results. Root-mean squared errors were additionally calculated with the Metrics package using the field observations and model predictions.

To test the effects of time, species (i.e., Acacia dealbata, E. nitens, E. pauciflora, and E. tenuiramis) and their interaction on the ZEB1-derived structural traits, a two-way mixedeffects model including plot as a random term was fitted to the individual tree data using the function "lme" of the package nlme. To account for the heterogeneity in the residual variances with time and the autocorrelation among observations inherent with repeat measure time series, an unstructured covariance matrix was used to model the dependencies among observations in the residual variance [26,27]. In each case, traits were transformed as required to optimize homogeneity of variances and normality based on the inspection of diagnostic plots following Zuur and Ieno [28]. Fixed effects were tested with the Walds F-test using the "anova.lme" function of nlme package, based on the marginal sum of squares. Least-squares means for fixed effects were calculated using the emmeans package.

\section{Results}

LiDAR-derived tree height, measured using the 99th height percentile, was highly correlated with the field measurements of tree height $\left(\mathrm{R}^{2}=0.90, \mathrm{RMSE}=0.34 \mathrm{~m}(2017)\right.$; $\mathrm{R}^{2}=0.96, \mathrm{RMSE}=0.27 \mathrm{~m}(2018) ; \mathrm{R}^{2}=0.97, \mathrm{RMSE}=0.24 \mathrm{~m}$ (2019)) (Figure 4a). Accordingly, the relationship between the averaged measurements of stem diameter taken in the field and those derived from a general allometric equation [24] using LiDAR traits as input (i.e., 99th height percentile and crown width at the widest point) resulted in relationships of $\mathrm{R}^{2}=0.54$ $($ RMSE $=1.12 \mathrm{~cm} ; 2017), 0.79($ RMSE $=3.61 \mathrm{~cm} ; 2018)$, and $0.74($ RMSE $=4.37 \mathrm{~cm} ; 2019)$ (Figure $4 \mathrm{~b}$ ). Two additional measures related to crown properties were also ground-truthed in this study: field-measured crown width was highly correlated with crown width at the widest cross-section $\left(\mathrm{R}^{2}=0.84, \mathrm{RMSE}=0.53 \mathrm{~m}(2018) ; \mathrm{R}^{2}=0.85, \mathrm{RMSE}=0.52 \mathrm{~m}(2019)\right)$, while field-measurements of crown insertion height were poorly correlated with a LiDAR composite value $\left(\mathrm{R}^{2}=0.18, \mathrm{RMSE}=0.29 \mathrm{~m}(2018) ; \mathrm{R}^{2}=0.09, \mathrm{RMSE}=0.30 \mathrm{~m}(2019)\right)$. This composite value derived from LiDAR was obtained after running a random forest model following Camarretta et al. [11], fitting the 99th height percentile, diameter, rumple index, and height to the widest cross-section as predictors of the field measured insertion height.

Irrespective of plot or monitoring year, the greatest number of gaps were observed below $1 \mathrm{~m}$, with the total area of gaps ranging from $188 \mathrm{~m}^{2}$ to $453 \mathrm{~m}^{2}$ (Figure 5). This lower layer of vegetation comprised a mosaic of variable sized gaps (data not shown), with the number of gaps increasing with age as the canopy of the trees grew taller (Figure 5). The total number of gaps generally decreased with increasing height of the vegetation within a plot. However, as the gaps reduced in number, the size of the gaps increased in area, suggesting a separation of the tree canopies from the lower vegetation layer and one another (Figure 5). 
(a)
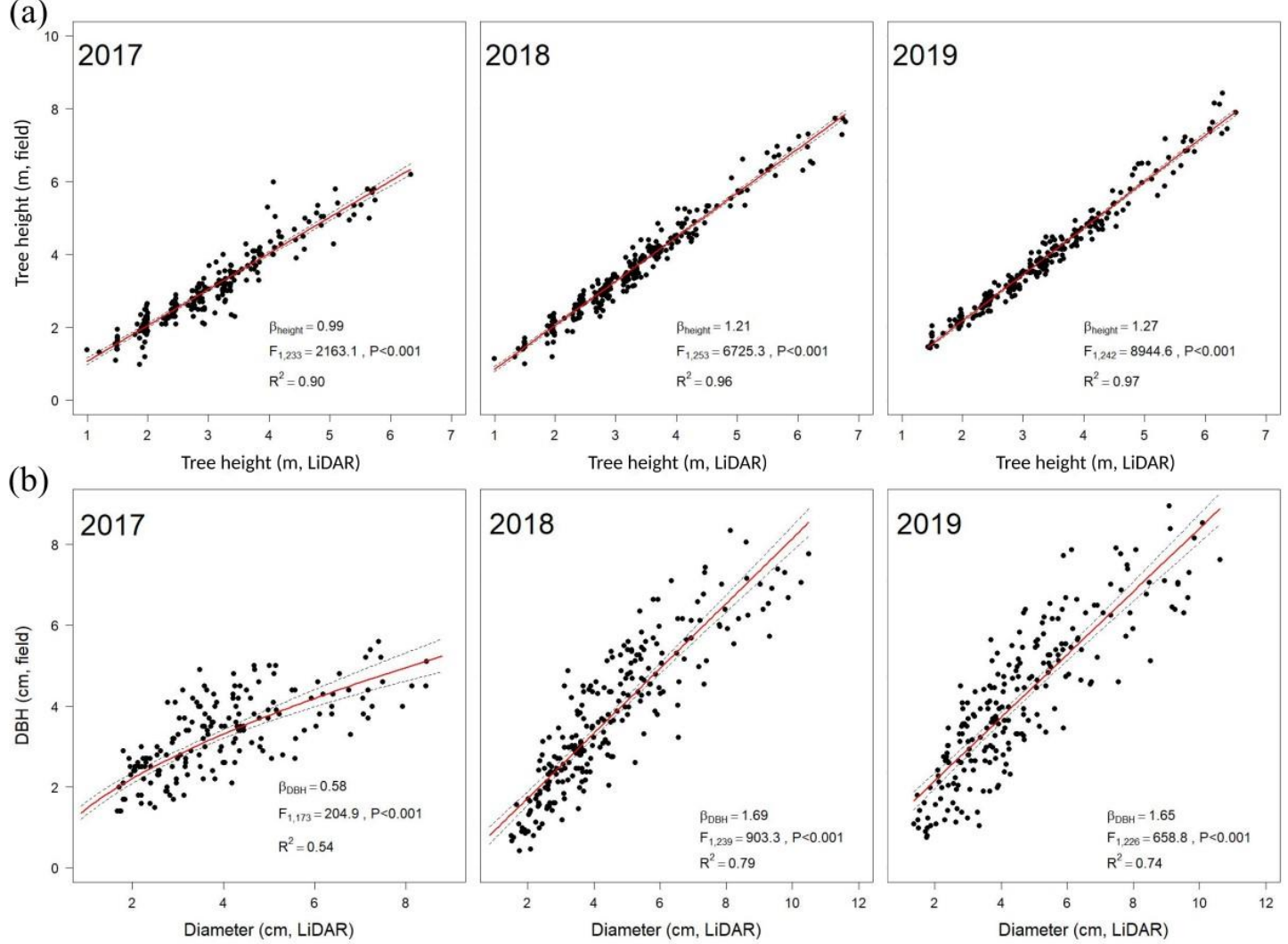

Figure 4. Validation regression plots (calculated for 240, 270, and 263 trees for 2017, 2018, and 2019, respectively) for tree height (a) and diameter at breast height (b).
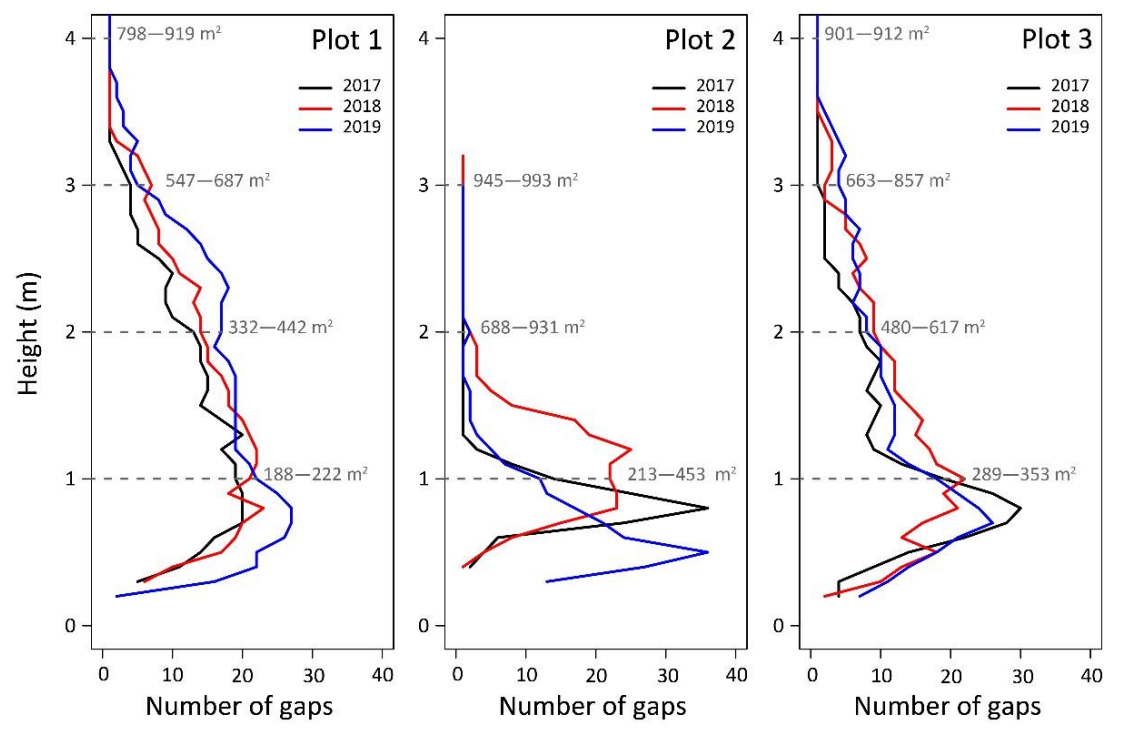

Figure 5. Dynamic gap analysis across the three monitoring plots for each monitoring year, showing the number of gaps in each vertical slice through the plot-level point cloud from $20 \mathrm{~cm}$ to $4 \mathrm{~m}$ above the ground. Each line corresponds to a monitoring year (black, 2017; red, 2018; blue, 2019). The grey text gives the estimated range for total size $\left(\mathrm{m}^{2}\right)$ of the gaps across the years for each meter interval.

During the manual digitization of tree crowns, several clusters of neighboring trees tended to have their crown either underneath or above that of other trees (Figure 3): 19 trees grouped into two clusters (6.9\% of the total) were found in 2017, 49 trees in 18 clusters (17.6\% of the total) were identified in 2018 and 70 trees from 25 clusters $(25.1 \%$ of the total) were present in 2019. This resulted in an overall crown overlap increase of $10.7 \%$ 
between 2017 and 2018, and of 7.5\% between 2018 and 2019. Based on the tree crowns that could be well-separated in each year, individual tree biomass averaged $2.86 \mathrm{~kg}$ (2017), $3.99 \mathrm{~kg}$ (2018), and $4.53 \mathrm{~kg}$ (2019), per tree, while overall biomass based on the resolved trees was $2285 \mathrm{~kg} / \mathrm{ha}(2017 ; n=240), 3590 \mathrm{~kg} / \mathrm{ha}(2018 ; n=270)$, and $3969 \mathrm{~kg} / \mathrm{ha}(2019$; $n=263)$. By 2019 there was a three-fold variation in AGB between plot $2(1672 \mathrm{~kg} / \mathrm{ha})$ and the other two plots (4711-5523 kg/ha), which is consistent with the differences in canopy occupancy as shown in Figure 1b. However, these plot-level trends do not account for biomass embedded in unresolved trees, which would downwardly bias the 2017 estimate.

The two-way fixed effect model indicated 13 of the 15 ZEB1 traits exhibited highly significant $(p<0.001)$ changes through time, all traits showed significant species difference $(p<0.01)$, and 9 traits exhibited significant time by species interaction at the 0.01 level (Table 3). Growth traits exhibited highly significant $(p<0.001)$ main and interaction effects, indicating a change in species performance through time. Eucalyptus nitens and E. tenuiramis had greater growth than E. pauciflora and Acacia dealbata in all years (Figure 6a,b). The time by species interaction for height was mainly due to E. tenuiramis surpassing E. nitens with time (particularly by 2018), and the growth difference between E. pauciflora and $A$. dealbata reducing with age (Figure $6 \mathrm{a}$ ). In the case of above-ground biomass, the significant interaction was mainly due to an increasing difference between the better and poorer growing species (Figure 6b). The distribution of points within the crown exhibited no significant time or interaction effects, but highly significant $(p<0.001)$ species differences. This suggests that crown distribution is a stable attribute of the species, with species developing denser upper crowns decreasing from $A$. dealbata $>$ E. pauciflora $>$ E. tenuiramis $>$ E. nitens (1.20 SE $( \pm 0.11), 1.03( \pm 0.06), 0.84( \pm 0.06)$, and $0.72( \pm 0.06)$, respectively). Crown roughness, as measured by the rumple index, varied significantly for all effects tested $(p<0.001)$. Crown roughness tended to increase with time and differed markedly between species, with E. tenuiramis having the most complex crowns and $A$. dealbata the least complex crowns (Figure 6c). Crown density was another notable trait, which differed markedly between species (Figure 6d). The faster growing E. tenuiramis and E. nitens had sparser crowns (low points to volume ratio) than E. pauciflora and A. dealbata. However, there was a significant time by species interaction due to the crown of the faster growing species (E. tenuiramis but mainly E. nitens) becoming sparser over the 2018 and 2019 period, whereas the crowns of the slower growing species became denser (E. pauciflora but mainly A. dealbata-Figure 6d).

Table 3. Analysis of variance results for all trees within the study, showing the trait transformation and F-statistic and its probability (Pr) for Time, Species, and their interactions terms. The numerator degrees of freedom (df) for each factor fitted is shown in the heading in parenthesis, and denominator degrees of freedom ranged between 719 and 759 according to the structural trait analysed. ${ }^{1}$ The trait descriptions are given in Table 2.

\begin{tabular}{|c|c|c|c|c|c|c|c|}
\hline \multirow{2}{*}{ Structural Traits } & \multirow{2}{*}{ Transformation } & \multicolumn{2}{|c|}{ Time $(\mathrm{df}=2)$} & \multicolumn{2}{|c|}{ Species $(\mathrm{df}=3)$} & \multicolumn{2}{|c|}{ Time Species $(\mathrm{df}=6)$} \\
\hline & & F & $\operatorname{Pr}$ & $\mathbf{F}$ & $\operatorname{Pr}$ & $\mathbf{F}$ & $\operatorname{Pr}$ \\
\hline Height P99 (m) & sqrt & 18.9 & $<0.001$ & 32.4 & $<0.001$ & 6.0 & $<0.001$ \\
\hline Crown skewness & $\ln$ & 2.5 & 0.082 & 9.8 & $<0.001$ & 1.3 & 0.250 \\
\hline Height of widest cross-section (m) & & 7.4 & $<0.001$ & 6.8 & $<0.001$ & 1.0 & 0.441 \\
\hline Max crown diameter $(\mathrm{m})$ & & 54.1 & $<0.001$ & 25.1 & $<0.001$ & 5.6 & $<0.001$ \\
\hline Crown volume (convex hull-m ${ }^{3}$ ) & sqrt & 15.9 & $<0.001$ & 31.4 & $<0.001$ & 5.7 & $<0.001$ \\
\hline Crown surface area $\left(\mathrm{m}^{2}\right)$ & sqrt & 18.0 & $<0.001$ & 27.6 & $<0.001$ & 4.3 & $<0.001$ \\
\hline Crown projected area $\left(\mathrm{m}^{2}\right)$ & sqrt & 18.1 & $<0.001$ & 27.1 & $<0.001$ & 7.7 & $<0.001$ \\
\hline Height to area ratio $\left(\mathrm{m} / \mathrm{m}^{2}\right)$ & $\ln$ & 9.8 & $<0.001$ & 17.9 & $<0.001$ & 2.5 & 0.021 \\
\hline Height to volume ratio $\left(\mathrm{m} / \mathrm{m}^{3}\right)$ & $\ln$ & 14.4 & $<0.001$ & 22.3 & $<0.001$ & 2.8 & 0.010 \\
\hline Points to area ratio (points $/ \mathrm{m}^{2}$ ) & sqrt & 5.3 & $<0.001$ & 16.0 & 0.005 & 4.4 & $<0.001$ \\
\hline Points to volume ratio (points $/ \mathrm{m}^{3}$ ) & sqrt & 1.5 & 0.226 & 25.4 & $<0.001$ & 2.4 & 0.027 \\
\hline Above Ground Biomass (AGB-kg) & $\ln$ & 17.9 & $<0.001$ & 29.1 & $<0.001$ & 3.7 & 0.001 \\
\hline Diameter at breast height $(\mathrm{m})$ & sqrt & 15.6 & $<0.001$ & 32.5 & $<0.001$ & 6.0 & $<0.001$ \\
\hline Rumple index & sqrt & 7.7 & $<0.001$ & 19.0 & $<0.001$ & 5.1 & $<0.001$ \\
\hline Area (3D:2D) & & 25.3 & $<0.001$ & 16.1 & $<0.001$ & 3.0 & 0.007 \\
\hline
\end{tabular}

1 Trees sampled per species varied slightly with year and trait, due to the crown of several smaller trees being unresolved from the understory in certain years and ranged from 12 to 19 for A. dealbata, 20 to 22 for E. nitens, 170 to 189 for E. pauciflora, and 38 to 41 for E. tenuiramis. 
(a)

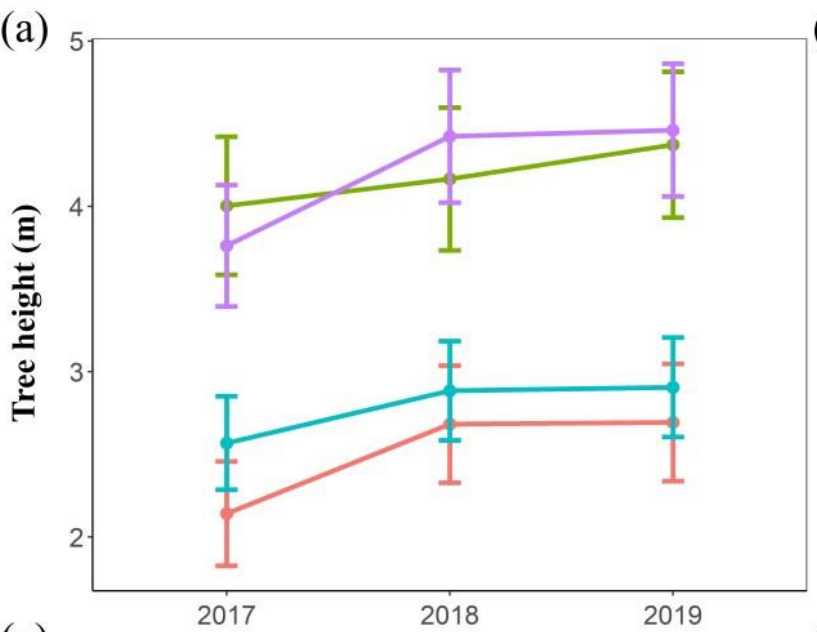

(c)

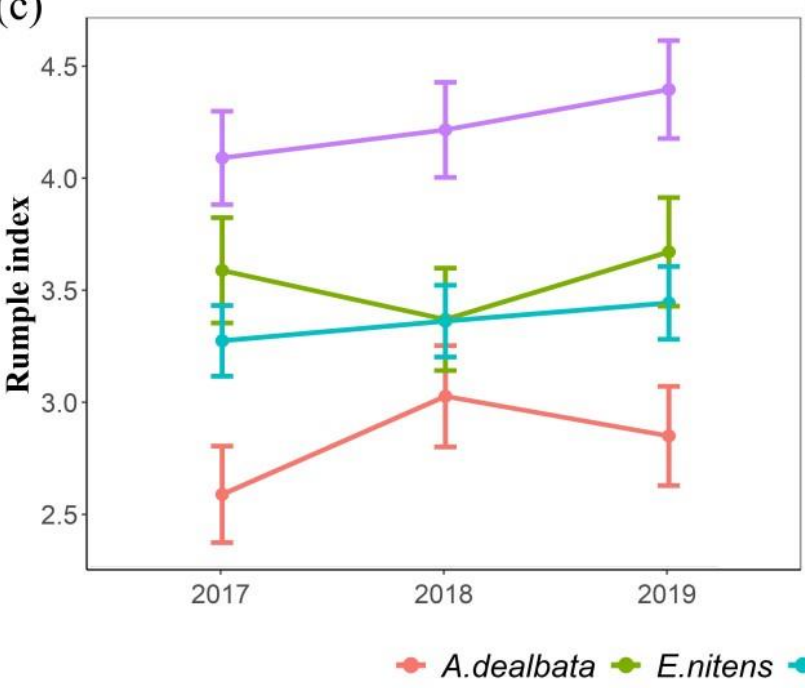

(b)

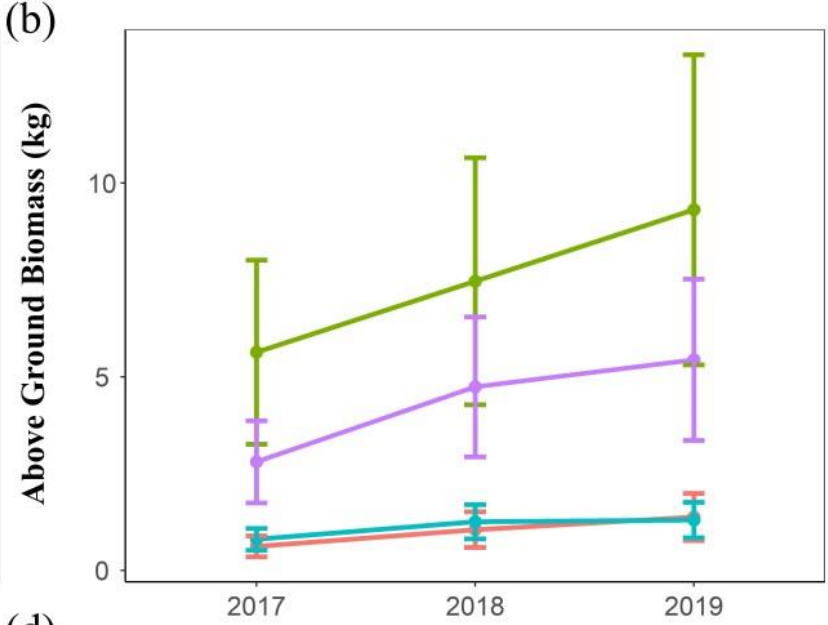

(d)

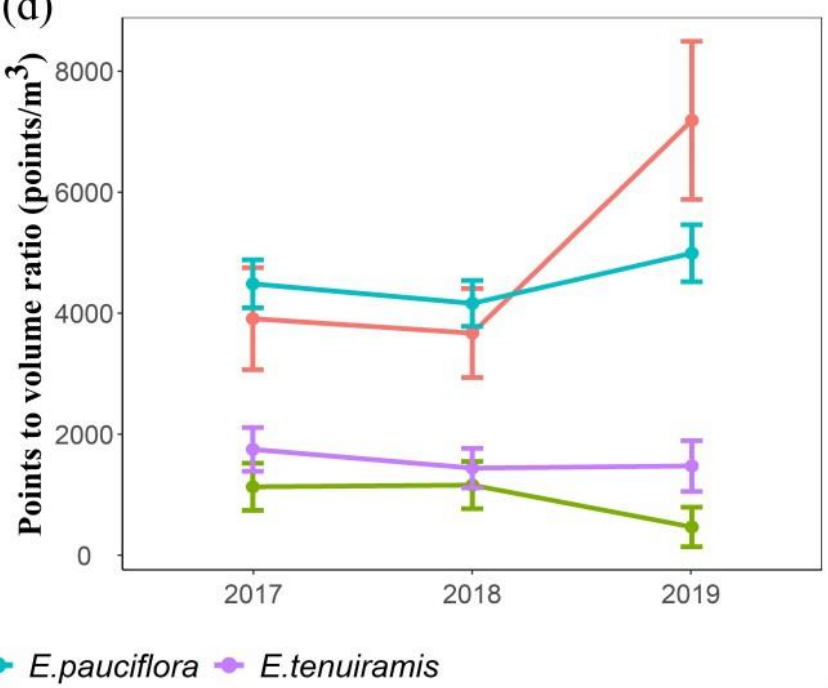

Figure 6. Species least-square mean plots across the three sampling years at the tree-levels estimated from the fitted model for tree height (a), above ground biomass (b), rumple index (c), and points to volume ratio (d).

\section{Discussion}

The validation results achieved for the four structural traits measured in the field were in strong agreement with the results previously obtained on a larger subset of the same restoration experiment using LiDAR mounted on a unmanned aerial vehicle (UAV) [11] and, more generally, with the broader ZEB1 literature [17,18,29]. Consistent with previous observations [11], crown insertion height was difficult to validate. This was largely attributed to the nature of these restoration species, with crowns extending to the bottom of the stem in many cases, making the separation from the underlying grassy layer particularly difficult. Nevertheless, the validation results for most traits tended to get better with time [30], which likely reflects tree crowns becoming wider and taller as the years passed. In addition, the canopy height models and gap analyses jointly indicated that vegetation layering is developing, with a mix of tall trees, medium sized trees/shrubs, as well as the formation of gaps and low vegetation. Due to the nature of the trees studied here (i.e., young age and mostly multi-stemmed), the application of 3D object modelling, such as cylinder fitting to the lower part of the tree stem [31,32], was not possible in this study. This method, which is mainly used in TLS studies, or more recently in below-canopy UAV flights $[31,33]$ is very promising, but we anticipate it would have provided extremely poor results under our present circumstances. Nonetheless, we imagine that as the trees grow taller and stems become more pronounced, a 3D object modelling approach could provide better results than those estimated from allometric equations. 
One emerging challenge from the present study was the detectability of individual tree crowns. The extraction of individual tree crowns from point clouds is a common problem with remotely sensed data [34,35]. In some cases (e.g., even-aged conifer forest), the development of automated crown extraction algorithms has proven very successful [35,36], but when trying to delineate crowns in uneven-aged mixed forest, results are still far from ideal $[37,38]$, with a recent study suggesting a bottom-up approach may provide segmentation accuracies greater than $85 \%$ in mixed species eucalypt forests [39]. In the present case, crowns were manually extracted from the point clouds and linked to the field planting grid and associated pedigree information. The vast majority of crowns in the three plots could be resolved in this study, allowing the full suite of structural traits to be assessed. However, a few problematic cases were identified and likely due to two major causes: (i) the crown of larger trees overlapping and shadowing neighboring smaller trees [40]; and (ii) problems related to the separation of crowns of small trees from the understory layer. Over time, neighboring trees started to exhibit canopy closure, which made individual tree crown extraction rather difficult [37], and in turn required additional manual pre-processing of the point clouds to obtain correctly segmented crowns. As noted above, in some cases the extracted individual point clouds could not allow computation of all structural traits including biomass, as it was not possible to detect where the understory layer ended, and the tree crown began. This is likely a confounding issue for the large increase in the estimated plot-level biomass from 2017 to 2018.

The 15 structural traits tested in the present study exhibited significant differences according to species, with a majority exhibiting significant differences across years and a time by species interaction. The species differences were mainly associated with differences in productivity among species. While survival of E. pauciflora was three-fold that of the other three species across the whole restoration area [21], the surviving trees of $E$. tenuiramis and E. nitens in the studied plots far exceeded E. pauciflora and A. dealbata in productivity at the individual tree-level. This height and biomass difference, however, was somewhat countered by the more productive species having sparser crowns. E. tenuiramis is a local species endemic to Tasmania and was represented in the plantings by provenances predominantly from lower altitude sources, which had been translocated up slope to compare with the local provenance and multiple provenances of E. pauciflora from higher and lower altitude than the planting site [21]. E. nitens is an Australian mainland species introduced onto the island for use in industrial plantations for pulpwood and solid wood production [41]. It is also often planted in smaller lots on Tasmanian farms, and in the present case, was tested as a nurse crop for E. pauciflora in the restoration plantings [21]. While E. nitens has previously shown reduced survival compared to E. pauciflora in coplantings in the dry Midlands environment [42], the superior height growth of survivors was only evident on one of the two sites tested [43]. Here, the introduced E. nitens have already greatly surpassed the co-planted, slower growing, E. pauciflora. This will likely trigger the next planned management action-a selective thinning of E. nitens individualsto add coarse woody debris to the restoration planting, opening new niches for dependent organisms to take advantage of, and increase the overall structural complexity.

As expected, tree height and biomass showed an increasing trend with time at the individual tree-level. However, a notable feature of our spatiotemporal data was the marked reduction in the growth increment over the 2018-2019 period compared with the 2017-2018 period in all species except $E$. nitens. This reduced growth corresponded with a below average rainfall in the 2018-2019 period, with the summer rainfall in January $(10.2 \mathrm{~mL})$ and February $(19.6 \mathrm{~mL})$ of 2019, being one of the lowest since the experiment was established (mean January and February precipitations for the 2011-2019 period are $30.4 \mathrm{~mL}$ and $26.2 \mathrm{~mL}$, respectively-www.bom.gov.au, accessed on 17 September 2017 (nearby Hermitage-Shannon River climate station)). One possible explanation is the reduced availability of water in the soil profile resulting in suppressed growth of E. tenuiramis, E. pauciflora, and A. dealbata over the monitoring period [44]. Indeed, water availability has been reported as one of the major factors explaining variation in the growth 
rate of E. globulus [45]. In contrast to these species, the height growth and predicted biomass of $E$. nitens remained more-or-less linear throughout the study period. This was unexpected, as the faster growing E. nitens is adapted to cooler moister environments [46] and would be expected to be more drought susceptible than the two native eucalypts. This contradiction could reflect reduced tree density in the E. nitens plots, due to previously higher mortality reducing the depletion of the soil-water store over this period (spacing effect on drought susceptibility [45]). Alternatively, it is possible that the faster growing E. nitens has established a larger and deeper root system at this age providing better access to stored soil water than the other species [47]. Nevertheless, it is possible that E. nitens is adjusting to water stress through the loss of canopy leaf area, which is a common response of eucalypts [44], which is supported by the observed decrease in canopy density observed over the 2018-2019 monitoring period.

The recent detection of different tree crown architectural properties deriving from different species and genetic provenances [11], raises the question on how these differences may affect dependent animal communities through changes in their use of available resources and feeding/nesting behavior. Previous studies have linked metrics of crown complexity (i.e., crown openness, vegetation layering, and cover) to arthropod [48,49], bird [50-52], mammal [8], and bat species richness [53]. Indeed, this is a particularly relevant topic in the fields of nature conservation and ecological restoration, as non-local plant material (i.e. non-local provenances) is increasingly been translocated though assisted migration strategies [54], such as climate-adjusted provenancing [55]. This introduction of non-local provenances (and in extreme cases, species replacement) with different crown properties compared to the local provenance (and species), could result in unexpected outcomes, such as loss of habitat-specialist species [56], which is opposite to the intended restoration goal. Additional research is therefore needed to begin to untangle the intricacies between species- and provenance-specific crown architectures and dependent species resource utilization and behavior. Finally, the ability to track the development of different structural attributes through time, as suggested in the present study, will enable land managers to make informed decisions to guide adaptive management of restoration plantings.

\section{Conclusions}

In this study, a hand-held laser scanning unit (ZEB1) was successfully used to capture 3D data from permanent forest restoration plots over a three-year period. The very high trait validation with ground-truth measurements suggest that this technology can successfully be employed as a faster alternative to traditional field surveys. Particularly, this technology allows the acquisition of ultra-dense 3D point clouds that can be used to derive a suite of structural traits rather than the few traits traditionally measured in field inventories. Indeed, the traditional field measurements carried out for the validation of the LiDARderived structural traits took several hours per plot, while the proximal scanning with ZEB1 took roughly 10 to 15 min per plot. While potentially reducing errors in traits measurement by reducing the human factor from traditional data collection (particularly difficult to measure traits), the use of such technology requires longer data processing and analysis when compared to traditional field techniques. Nevertheless, in this case, with the exception of crown segmentation, data processing and analysis were extremely fast, as the analysis pipeline developed in $\mathrm{R}$ was easily and automatically applicable. While significant spatiotemporal changes in forest structural traits (both validated and not) important for habitat provision and biodiversity were detected, a potential drawback was identified during this study. Permanent plot identification and establishment needs to be carefully planned to ensure that data co-registration is possible through time. On the one hand, this can reduce the potential application of the ZEB1 system for forest restoration monitoring, as it may require access to specialized equipment and personnel necessary for the establishment of a GNSS base station. However, if data geolocation is not considered necessary, permanent plot establishment, like the one defined in Section 2.2 will still allow scan co-registration over time. Although this technology has been shown to provide 
rapid inventory of forest plots $[29,57,58]$, its uptake by forest restoration ecologists for the monitoring of restoration plantings is still lagging. The present study demonstrates the potential of remote sensing technology, and particularly the ZEB1 system, to monitor the development of structural traits over time to guide adaptive management and report on restoration effectiveness.

Author Contributions: Conceptualization, N.C.; Methodology, N.C., P.A.H., and B.M.P.; Software, P.A.H., N.C., and B.M.P.; Validation, N.C., B.M.P., and P.A.H.; Formal Analysis, N.C., P.A.H., and B.M.P.; Investigation, N.C., B.M.P., and P.A.H.; Resources, A.L. and M.H.; Data Curation, N.C., A.L., and P.A.H.; Writing-Original Draft Preparation, N.C.; Writing-Review \& Editing, P.A.H., M.H., A.L., B.M.P., and N.D.; Visualization, N.C.; Supervision, P.A.H., B.M.P., A.L., and M.H.; Project Administration, N.C.; Funding Acquisition, M.H. and B.M.P. All authors have read and agreed to the published version of the manuscript.

Funding: Trial establishment was supported by a Tasmanian State Government grant to offset government carbon emissions (offered to Greening Australia by then Premier Jim Bacon) as well as an Australian Research Council (ARC) Linkage Grant (LP0991026) held in partnership with Greening Australia. The ARC Industrial Transformation Training Centre for Forest Value (IC150100004) provided further support including a PhD scholarship for NC. This publication was supported financially by the Open Access Grant Program of the German Research Foundation (DFG) and the Open Access Publication Fund of the University of Göttingen.

Institutional Review Board Statement: Not applicable.

Informed Consent Statement: Not applicable.

Data Availability Statement: Tree data relating to this study are available upon request at: https: / / rdp.utas.edu.au/metadata/f9041839-cd71-4648-9b64-7cefc61f1576 (accessed on 19 April 2021).

Acknowledgments: We thank Woodlea Nursery for plant production, Tanya Bailey, Paul Tilyard, Michelle Balasso, Chenglei Wang, Hugh Fitzgerald, Antje Lai-Yen Chiu Werner, Akira Weller-Wong, and Dalila Pasquini for their assistance with field work.

Conflicts of Interest: The authors declare no conflict of interest.

\section{References}

1. Perring, M.P.; Standish, R.J.; Price, J.N.; Craig, M.D.; Erickson, T.E.; Ruthrof, K.X.; Whiteley, A.S.; Valentine, L.E.; Hobbs, R.J Advances in restoration ecology: Rising to the challenges of the coming decades. Ecosphere 2015, 6, art131. [CrossRef]

2. Maginel, C.J.; Knapp, B.O.; Kabrick, J.M.; Olson, E.K.; Muzika, R.-M. Floristic quality index for woodland ground flora restoration: Utility and effectiveness in a fire-managed landscape. Ecol. Indic. 2016, 67, 58-67. [CrossRef]

3. Noss, R.F. Indicators for monitoring biodiversity: A hierarchical approach. Conserv. Biol. 1990, 4, 355-364. [CrossRef]

4. McElhinny, C.; Gibbons, P.; Brack, C.; Bauhus, J. Forest and woodland stand structural complexity: Its definition and measurement. For. Ecol. Manag. 2005, 218, 1-24. [CrossRef]

5. Kormann, U.; Scherber, C.; Tscharntke, T.; Klein, N.; Larbig, M.; Valente, J.J.; Hadley, A.S.; Betts, M.G. Corridors restore animal-mediated pollination in fragmented tropical forest landscapes. Proc. R. Soc. B Biol. Sci. 2016, 283, 20152347. [CrossRef] [PubMed]

6. Chazdon, R.L. Beyond Deforestation: Restoring Forests and Ecosystem Services on Degraded Lands. Science 2008, 320, 1458-1460. [CrossRef] [PubMed]

7. MacArthur, R.H.; MacArthur, J.W. On bird species diversity. Ecology 1961, 42, 594-598. [CrossRef]

8. Davies, A.B.; Ancrenaz, M.; Oram, F.; Asner, G.P. Canopy structure drives orangutan habitat selection in disturbed Bornean forests. Proc. Natl. Acad. Sci. USA 2017, 114, 8307-8312. [CrossRef]

9. Camarretta, N.; Harrison, P.A.; Bailey, T.; Potts, B.; Lucieer, A.; Davidson, N.; Hunt, M. Monitoring forest structure to guide adaptive management of forest restoration: A review of remote sensing approaches. New For. 2019, 1-24. [CrossRef]

10. Cordell, S.; Questad, E.J.; Asner, G.P.; Kinney, K.M.; Thaxton, J.M.; Uowolo, A.; Brooks, S.; Chynoweth, M.W. Remote sensing for restoration planning: How the big picture can inform stakeholders. Restor. Ecol. 2017, 25, S147-S154. [CrossRef]

11. Camarretta, N.; A Harrison, P.; Lucieer, A.; M Potts, B.; Davidson, N.; Hunt, M. From Drones to Phenotype: Using UAV-LiDAR to Detect Species and Provenance Variation in Tree Productivity and Structure. Remote Sens. 2020, 12, 3184. [CrossRef]

12. Vepakomma, U.; Cormier, D. Potential of multi-temporal UAV-borne lidar in assessing effectiveness of silvicultural treatments. Int. Arch. Photogramm. Remote Sens. Spat. Inf. Sci. ISPRS Arch. 2017, 42, 393-397. [CrossRef]

13. Næsset, E.; Gobakken, T. Estimation of above- and below-ground biomass across regions of the boreal forest zone using airborne laser. Remote Sens. Environ. 2008, 112, 3079-3090. [CrossRef] 
14. Price, O.F.; Gordon, C.E. The potential for LiDAR technology to map fire fuel hazard over large areas of Australian forest. J. Environ. Manag. 2016, 181, 663-673. [CrossRef]

15. Muir, J.; Phinn, S.; Eyre, T.; Scarth, P. Measuring plot scale woodland structure using terrestrial laser scanning. Remote Sens. Ecol. Conserv. 2018, 4, 320-338. [CrossRef]

16. Marselis, S.M.; Yebra, M.; Jovanovic, T.; van Dijk, A. Deriving comprehensive forest structure information from mobile laser scanning observations using automated point cloud classification. Environ. Model. Softw. 2016, 82, 142-151. [CrossRef]

17. Bauwens, S.; Bartholomeus, H.; Calders, K.; Lejeune, P. Forest inventory with terrestrial LiDAR: A comparison of static and hand-held mobile laser scanning. Forests 2016, 7, 127. [CrossRef]

18. Ryding, J.; Williams, E.; Smith, M.; Eichhorn, M. Assessing handheld mobile laser scanners for forest surveys. Remote Sens. 2015, 7, 1095. [CrossRef]

19. Jaakkola, A.; Hyyppä, J.; Yu, X.; Kukko, A.; Kaartinen, H.; Liang, X.; Hyyppä, H.; Wang, Y. Autonomous collection of forest field reference-The outlook and a first step with UAV laser scanning. Remote Sens. 2017, 9, 785. [CrossRef]

20. Bailey, T.G.; Harrison, P.A.; Davidson, N.; Weller-Wong, A.; Tilyard, P.; Steane, D.; Vaillancourt, R.E.; Potts, B.M. Embedding genetics experiments in restoration to assist in plant choice for a degraded landscape with a changing climate. Ecol. Manag. Restor. 2021, 999, 999.

21. Camarretta, N.; Harrison, P.A.; Bailey, T.; Davidson, N.; Lucieer, A.; Hunt, M.; Potts, B.M. Stability of species and provenance performance when translocated into different community assemblages. Restor. Ecol. 2020, 28, 447-458. [CrossRef]

22. GEOSLAM. ZEB1 User Guide; v3.0.1.; GeoSLAM Ltd.: Nottingham, UK, 2015; v3.0.1.

23. R Core Team. R: A Language and Environment for Statistical Computing. Available online: https://www.r-project.org (accessed on 9 January 2017).

24. Jucker, T.; Caspersen, J.; Chave, J.; Antin, C.; Barbier, N.; Bongers, F.; Dalponte, M.; van Ewijk, K.Y.; Forrester, D.I.; Haeni, M.; et al. Allometric equations for integrating remote sensing imagery into forest monitoring programmes. Glob. Chang. Biol. 2017, 23, 177-190. [CrossRef] [PubMed]

25. Silva, C.A.; Valbuena, R.; Pinagé, E.R.; Mohan, M.; de Almeida, D.R.A.; North Broadbent, E.; Jaafar, W.S.W.M.; de Almeida Papa, D.; Cardil, A.; Klauberg, C. ForestGapR: An r Package for forest gap analysis from canopy height models. Methods Ecol. Evol. 2019, 10, 1347-1356. [CrossRef]

26. Wolfinger, R.D. Heterogeneous variance-covariance structures for repeated measures. J. Agric. Biol. Environ. Stat. 1996, 1, 205-230. [CrossRef]

27. Pinheiro, J.C.; Bates, D.M. Unconstrained parametrizations for variance-covariance matrices. Stat. Comput. 1996, 6, 289-296. [CrossRef]

28. Zuur, A.F.; Ieno, E.N. A protocol for conducting and presenting results of regression-type analyses. Methods Ecol. Evol. 2016, 7, 636-645. [CrossRef]

29. Del Perugia, B.; Giannetti, F.; Chirici, G.; Travaglini, D. Influence of scan density on the estimation of single-tree attributes by hand-held mobile laser scanning. Forests 2019, 10, 277. [CrossRef]

30. Tompalski, P.; Rakofsky, J.; Coops, N.C.; White, J.C.; Graham, A.N.V.; Rosychuk, K. Challenges of multi-temporal and multi-sensor forest growth analyses in a highly disturbed boreal mixedwood forests. Remote Sens. 2019, 11, 2102. [CrossRef]

31. Hyyppä, E.; Yu, X.; Kaartinen, H.; Hakala, T.; Kukko, A.; Vastaranta, M.; Hyyppä, J. Comparison of backpack, handheld, under-canopy UAV, and above-canopy UAV laser scanning for field reference data collection in boreal forests. Remote Sens. 2020, 12, 3327. [CrossRef]

32. Puletti, N.; Grotti, M.; Scotti, R. Evaluating the Eccentricities of Poplar Stem Profiles with Terrestrial Laser Scanning. Forests 2019, 10, 239. [CrossRef]

33. Krisanski, S.; Taskhiri, M.S.; Turner, P. Enhancing methods for under-canopy unmanned aircraft system based photogrammetry in complex forests for tree diameter measurement. Remote Sens. 2020, 12, 1652. [CrossRef]

34. Harikumar, A.; Bovolo, F.; Bruzzone, L. A local projection-based approach to individual tree detection and 3-d crown delineation in multistoried coniferous forests using high-density airborne LiDAR data. IEEE Trans. Geosci. Remote Sens. 2019, 57, 1168-1182. [CrossRef]

35. Dalponte, M.; Frizzera, L.; Gianelle, D. How to map forest structure from aircraft, one tree at a time. Ecol. Evol. 2018, 8, 5611-5618. [CrossRef] [PubMed]

36. Kaartinen, H.; Hyyppä, J.; Yu, X.; Vastaranta, M.; Hyyppä, H.; Kukko, A.; Holopainen, M.; Heipke, C.; Hirschmugl, M.; Morsdorf, F.; et al. An international comparison of individual tree detection and extraction using airborne laser scanning. Remote Sens. 2012, 4, 950-974. [CrossRef]

37. Millikan, P.H.K.; Silva, C.A.; Rodriguez, L.C.E.; Oliveira, T.M.; Carvalho, M.P.L.C.; Carvalho, S.P.C. Automated individual tree detection in Amazon tropical forest from airborne laser scanning data. CERNE 2019, 25, 273-282. [CrossRef]

38. Hastings, J.H.; Ollinger, S.V.; Ouimette, A.P.; Sanders-DeMott, R.; Palace, M.W.; Ducey, M.J.; Sullivan, F.B.; Basler, D.; Orwig, D.A. Tree species traits determine the success of LiDAR-based crown mapping in a mixed temperate forest. Remote Sens. 2020, 12, 309. [CrossRef]

39. Jaskierniak, D.; Lucieer, A.; Kuczera, G.; Turner, D.; Lane, P.N.J.; Benyon, R.G.; Haydon, S. Individual tree detection and crown delineation from Unmanned Aircraft System (UAS) LiDAR in structurally complex mixed species eucalypt forests. ISPRS J. Photogramm. Remote Sens. 2021, 171, 171-187. [CrossRef] 
40. Dalponte, M.; Coomes, D.A. Tree-centric mapping of forest carbon density from airborne laser scanning and hyperspectral data. Methods Ecol. Evol. 2016, 7, 1236-1245. [CrossRef]

41. Hamilton, M.; Joyce, K.; Williams, D.; Dutkowski, G.; Potts, B. Achievements in forest tree improvement in Australia and New Zealand 9. Genetic improvement of Eucalyptus nitens in Australia. Aust. For. 2008, 71, 82-93. [CrossRef]

42. Close, D.C.; Davidson, N.J.; Churchill, K.C.; Grosser, P. Evaluation of establishment techniques on Eucalyptus nitens and E. pauciflora in the Midlands of Tasmania. Ecol. Manag. Restor. 2005, 6, 149-151. [CrossRef]

43. Close, D.C.; Davidson, N.J.; Churchill, K.C.; Corkrey, R. Establishment of native Eucalyptus pauciflora and exotic Eucalyptus nitens on former grazing land. New For. 2010, 40, 143-152. [CrossRef]

44. Whitehead, D.; Beadle, C.L. Physiological regulation of productivity and water use in Eucalyptus: A review. For. Ecol. Manag. 2004, 193, 113-140. [CrossRef]

45. White, D.A.; Crombie, D.S.; Kinal, J.; Battaglia, M.; McGrath, J.F.; Mendham, D.S.; Walker, S.N. Managing productivity and drought risk in Eucalyptus globulus plantations in south-western Australia. For. Ecol. Manag. 2009, 259, 33-44. [CrossRef]

46. Wardlaw, T. A Climate Analysis of the Current and Potential Future Eucalyptus Nitens and E. globulus Plantation Estate on Tasmanian State Forest. Tasforests 2017, 19, 17-27.

47. Tomlinson, K.W.; Sterck, F.J.; Bongers, F.; da Silva, D.A.; Barbosa, E.R.M.; Ward, D.; Bakker, F.T.; van Kaauwen, M.; Prins, H.H.T.; de Bie, S.; et al. Biomass partitioning and root morphology of savanna trees across a water gradient. J. Ecol. 2012, 100, 1113-1121. [CrossRef]

48. Müller, J.; Bae, S.; Röder, J.; Chao, A.; Didham, R.K. Airborne LiDAR reveals context dependence in the effects of canopy architecture on arthropod diversity. For. Ecol. Manag. 2014, 312, 129-137. [CrossRef]

49. Setiawan, N.N.; Vanhellemont, M.; Baeten, L.; Gobin, R.; De Smedt, P.; Proesmans, W.; Ampoorter, E.; Verheyen, K. Does neighbourhood tree diversity affect the crown arthropod community in saplings? Biodivers. Conserv. 2016, 25, 169-185. [CrossRef]

50. Müller, J.; Stadler, J.; Brandl, R. Composition versus physiognomy of vegetation as predictors of bird assemblages: The role of lidar. Remote Sens. Environ. 2010, 114, 490-495. [CrossRef]

51. Munro, N.T.; Fischer, J.; Barrett, G.; Wood, J.; Leavesley, A.; Lindenmayer, D.B. Bird's response to revegetation of different structure and floristics-Are "restoration plantings" restoring bird communities? Restor. Ecol. 2011, 19, 223-235. [CrossRef]

52. North, M.P.; Kane, J.T.; Kane, V.R.; Asner, G.P.; Berigan, W.; Churchill, D.J.; Conway, S.; Gutiérrez, R.J.; Jeronimo, S.; Keane, J.; et al. Cover of tall trees best predicts California spotted owl habitat. For. Ecol. Manag. 2017, 405, 166-178. [CrossRef]

53. Froidevaux, J.S.P.; Zellweger, F.; Bollmann, K.; Jones, G.; Obrist, M.K. From field surveys to LiDAR: Shining a light on how bats respond to forest structure. Remote Sens. Environ. 2016, 175, 242-250. [CrossRef]

54. Aitken, S.N.; Whitlock, M.C. Assisted gene flow to facilitate local adaptation to climate change. Annu. Rev. Ecol. Evol. Syst. 2013, 44, 367-388. [CrossRef]

55. Prober, S.M.; Byrne, M.; McLean, E.H.; Steane, D.A.; Potts, B.M.; Vaillancourt, R.E.; Stock, W.D. Climate-adjusted provenancing: A strategy for climate-resilient ecological restoration. Front. Ecol. Evol. 2015, 3, 40-53. [CrossRef]

56. Hanzelka, J.; Reif, J. Effects of vegetation structure on the diversity of breeding bird communities in forest stands of non-native black pine (Pinus nigra A.) and black locust (Robinia pseudoacacia L.) in the Czech Republic. For. Ecol. Manag. 2016, 379, 102-113. [CrossRef]

57. Chen, S.; Liu, H.; Feng, Z.; Shen, C.; Chen, P. Applicability of personal laser scanning in forestry inventory. PLoS ONE 2019, 14, e211392. [CrossRef] [PubMed]

58. Vatandaşlar, C.; Zeybek, M. Application of handheld laser scanning technology for forest inventory purposes in the NE Turkey. Turkish J. Agric. For. 2020, 229-242. [CrossRef] 